\title{
WORKING-CLASS HOUSING IN BIRMINGHAM DURING THE INDUSTRIAL REVOLUTION
}

It is not too much to say that over the last twenty years the history of working-class housing in the nineteenth century has been transformed. Many older historians, of course, took it for granted that the quality of houses built to meet the needs of the fast-growing urban population was uniformly bad, a testimony to the avarice of builders and landlords alike. Beliefs of this kind owed much to Engels, and to the Hammonds writing earlier this century about the life of the town labourter. ${ }^{1}$ One of the first suggestions that these views were really an over-simplified description of housing conditions came from Professor Ashworth in the 1950's, who pointed out that it was quite wrong to suppose that all nineteenth-century towns developed on the same lines, a kind of Coketown endlessly repeated. ${ }^{2}$ While not denying that there was a great deal of poor-quality building, more recently historians have made it clear that newer town housing of the late eighteenth and early nineteenth centuries was not necessarily worse than housing built earlier on, or worse than rural housing built at the same time; that new building varied in construction and amenities in the same town, and from town to town; that the skilled working classes were likely to live in better-quality housing than the unskilled; and that the segregation of working-class housing from middle-class housing, and of the better-off working classes from the labouring classes, again varied from town to town. ${ }^{3}$

${ }^{1} \mathrm{~F}$. Engels, The Condition of the Working Class in England, transl, and ed. by W. O. Henderson and W. H. Chaloner (1958), ch. III, particularly pp. $58 \mathrm{ff}$, ; his praise of betterquality building in, for example, Ashton-under-Lyme, p. 52, is not often quoted; J. L. and B. Hammond, The Town Labourer (1917); id., The Bleak Age (1934).

2 W. Ashworth, Genesis of English Town Planning (1954), p. 15.

${ }^{3}$ For a recent local study of a town in the Black Country which touches on all these aspects, and refers to some of the more modern books on nineteenth-century housing, see E. Hopkins, "Working-Class Housing in the Smaller Industrial Town in the Nineteenth Century: Stourbridge - A Case Study", in: Midland History, IV (1978). Among the numerous and valuable urban studies of the past few years, see P. J. Corfield, The 
How is working-class housing in Birmingham during the Industrial Revolution to be seen against this background? Of the major industrial cities, Birmingham has received less attention in this respect in modern historical works than any other city. Indeed, general works on the history of working-class housing in the nineteenth century take little notice of Birmingham save in connection with Joseph Chamberlain's clearance scheme of the 1880 's (and then it is often to give rather more credit to the achievements of the scheme than is justified). But what of the new housing of the second half of the eighteenth century and the first half of the nineteenth century, the classic period of population growth and increasing industrialisation? It is the purpose of this paper to attempt to provide an overall view of the development of working-class housing in Birmingham in this period, and to place that development into some sort of national perspective.

The population of Birmingham grew at a striking rate in the eighteenth century, and it was a growth by no means confined to the second half of the century. According to Dr Chalklin, the population of Birmingham was between 5,000 and 7,000 in 1700, and in the next half century it at least trebled, and possibly quadrupled, to reach $23,688 .{ }^{4}$ This was in a period in which the national population is estimated to have risen from 5,100,000 at the beginning of the century to $5,800,000$, an increase of less than 20 per cent. ${ }^{5}$ Only one other town appears to have surpassed Birmingham in population growth at this time: Sheffield grew from less than 3,500 in 1700 to 12,000 in 1757. By 1750 , Norwich and Bristol were still the largest provincial towns, but the next biggest was Birmingham. ${ }^{6}$

In the following fifty years the high rate of growth continued. By 1770 the population had reached about 31,000 , and it increased by more than 50 per cent in the next eighteen years to 48,253 in 1778 . Between that date and

Impact of English Towns 1700-1800 (1982); M. J. Daunton, House and Home in the Victorian City. Working Class Housing 1850-1914 (1983); The Pursuit of Urban History, ed. by D. Fraser and A. Sutcliffe (1983); The Transformation of English Provincial Towns 1600-1800, ed. by P. Clark (1984); R. Dennis, English Industrial Cities of the Nineteenth Century (1984)

${ }^{4}$ C. W. Chalklin, The Provincial Towns of Georgian England. A Study of the Building Process $1740-1820$ (1974), p. 22. This book is an excellent guide to house building in Birmingham during the eighteenth century, and provides the best modern account of the subject.

${ }^{5}$ E. A. Wrigley and R. S. Schofield, The Population History of England, 1571-1871 (1981), pp. 208-09. For population figures for other large towns, see C. M. Law, "Some Notes on the Urban Population of England and Wales in the Eighteenth Century", in: The Local Historian, X (1972).

${ }^{6}$ Chalklin, The Provincial Towns, op. cit., pp. 22, 25. 
1791 there was a further growth of about 46 per cent, but thereafter the rate of increase dropped sharply with the onset of war with France in 1793. In the next century growth was resumed, but at a slower pace. Whereas in the previous half century the Birmingham population appears to have increased by more than three times (well ahead of the estimated national increase of about 50 per cent), in the period 1801-41 it increased by only two and a half times, not much more than the national rate, and markedly less than the rate in some other industrial towns. Thus there seems to have been a faster rate of expansion and a greater need for additional housing before 1801 than in the decades which followed. ${ }^{7}$

Evidently there was no shortage of land for building in the central areas in the eighteenth century. In some cases open tracts of land were made available for building by private Act of Parliament; for example, the Colmore Estate Act (1746) opened up the Northern flank of the ridge between Easy Hill and Snow Hill, while St Martin's glebe land covering 23 acres at Five Ways was the subject of another act in $1773 .{ }^{8}$ Much additional building was the result of the infilling of gardens and orchards belonging to the houses of middle-class residents in the middle of the town. ${ }^{9}$ Other housing was provided on the periphery, especially to the south in the more industrialised district of Deritend. After the turn of the century, the main areas of building were to the north and north-west of the town, in the area of Warstone Lane, Great Hampton Street and New John Street West. By the 1830 's this area was becoming more closely packed, and by 1838 there was similarly little undeveloped land in the Eastern half of the parish. Curiously enough, small allotment gardens (the well-known guinea-andhalf-guinea gardens) still ringed the central area on the west, north and east in the 1830 's. ${ }^{10}$

The kind of working-class house built in the second half of the eighteenth century in Birmingham varied in design from the most numerous, which consisted of two rooms per floor, arranged in two or three stories and built around courts, to back-to-backs consisting of only two rooms, one up and

${ }^{7}$ For population figures in this paragraph, see ibid., pp. 266, 275; Victoria History of the County of Warwick, VII: The City of Birmingham, ed. by W. B. Stephens (1964), p. 8; and the printed Census Returns, 1801-41.

8 The City of Birmingham, pp. 8-9.

9 This is well-attested. Birmingham was essentially a development of the early-modern period, lacking the densely packed central areas of some of the older towns. In the mid eighteenth century, there were still plenty of middle-class houses with their own grounds in Central Birmingham, J. A. Langford, A Century of Birmingham Life: or, a Chronicle of Local Events, from 1741 to 1841 (2 vols; 1868), I, p. 102.

${ }_{10}$ The City of Birmingham, pp. 9-10. 
$£ 40$ to $£ 60$, while most building-club houses, which were rather larger, cost between $£ 80$ and $£ 150 .{ }^{11}$ Ownership of the smaller houses seems to have been spread over a spectrum of occupations, not excluding the more prosperous working classes themselves, who purchased their own homes through the building clubs. Smaller entrepreneurs were also prominent as owners. For example, in 1765 two bricklayers (probably jobbing builders) took out Sun insurance policies on the houses they owned: Henry Gough insured four houses for $£ 220$, and another four houses for $£ 170$, while James Day insured eleven houses and a schoolhouse, their values ranging from $£ 65$ to $£ 15 .{ }^{12}$ Many holders of other Sun policies issued in the same year were small masters in the toy, button, buckle, gun and woodwork trades, and were similarly insuring a number of small properties let out to others.

It is not possible to say very much about the quality of these working-class houses built in the second half of the eighteenth century. Contemporary references to the amount of building going on are common, but without any account of the manner and style of building. Thus, B. Faujas de St Fond estimated that during the war with the American colonists (1776-83) at least 300 houses were built annually, and after peace was concluded this rate doubled. Whole streets were being erected, and a complete street might go up in less than two months. ${ }^{13}$ Hutton, the historian of Birmingham, also commented on the extent of building, suggesting that "Perhaps more are erected here, in a given time, than in any place in the whole island, London excepted." But he did go on to refer to the lack of any overall control of the methods employed by builders, and considered that as a result there arose "evils without a cure; such as narrowness, which scarcely admits light, cleanliness, pleasure, health, or use" ${ }^{14}$ Presumably this is a reference to the narrow entrances of some of the older courts, which will be mentioned again later; and it is a reasonable assumption that some of the houses put up so speedily were of poor quality, particularly during the war period at the end of the century, when there was an increase in the cost of building materials (especially timber), and builders made do with the cheapest materials available. On the other hand, some good-quality building did take place. About 90 houses built on land belonging to the Lench Charity Trust after 1752 were described in the 1920's as mostly still standing "in a one down. The majority sold for well under $£ 100$, the smallest selling for

1 Chalklin, The Provincial Towns, pp. 196-200.

12 Sun Insurance Registers, policies Nos 221,313 (dated 2 July 1765) and 226,998 (dated 13 November 1765), London Guildhall Library, Ms. 11936/158.

${ }^{13}$ B. Faujas de St Fond, A Journey through England and Scotland to the Hebrides in 1784 (2 vols; 1907), II, pp. 348-49.

${ }_{14}$ W. Hutton, History of Birmingham, 4th ed. (1809), pp. 71, 77. 
state of good repair and occupied by respectable tenants, and likely to stand for another thirty or forty years". ${ }^{15}$

The results of the building developments of the period 1760-1840 may be surveyed in the public-health reports of the 1840's. ${ }^{16}$ The 1840 Report of the Select Committee considered that Birmingham was in a rather better state than some other industrial towns. They summed up their conclusions by stating that

The great town of Birmingham [. . . ] appears to form rather a favourable contrast, in several particulars, with the state of other large towns. [. . .] the general custom of each family living in a separate dwelling is conducive to comfort and cleanliness, and the good site of the town, and the dry and absorbent nature of the soil, are very great natural advantages. ${ }^{17}$

These advantages are dwelt upon in detail in the report. There were no cellar dwellings in the town, unlike Liverpool or Manchester, and the water supply was very good. Generally speaking, the streets and drainage were "very superior to those in Manchester and other towns in Lancashire". All the leading streets had underground drainage, though there were some open sewers in Bordesley and Deritend, areas inhabited by the working classes. ${ }^{18}$ The principal witness, Dr Joseph Hodgson, considered that fever was comparitively rare in Birmingham; it was a very healthy town. He had seen "the abodes of the poor" in Liverpool, Manchester and London, and he thought the poor in Birmingham were much better off. Admittedly there were some close courts in the old part without free access of air, but not many in the modern parts. There were many back-to-back houses, too, but this type of house was not always inferior to other types of houses. Hodgson's strongest criticism was directed at the lodging houses, which he thought were great sources of disease. ${ }^{19}$ On the whole, he touched only lightly on the state of some of the older courts, and it was left to Thomas Cubitt, the London builder, to give his opinion that there were many close courts in Birmingham "which appear to be in a very bad state". ${ }^{20}$

${ }_{15}$ Chalklin, The Provincial Town, p. 313.

16 These are the Report of the Health of Towns Select Committee [Parliamentary Papers, 1840, XI] (hereafter 1840 Report), the Report on the Sanitary Condition of the Labouring Population of Great Britain [PP, 1842, XXVII] (hereafter Chadwick's Report), and the two Reports of the Commissioners of Inquiry into the State of Large Towns and Populous Districts [PP, 1844, XVII, and 1845, XVIII] (hereafter 1844 Report and 1845 Report).

171840 Report, p. xii.

${ }^{18}$ Ibid., pp. 136-37.

19 Ibid., pp. 176-79.

20 Ibid., p. 204. 
The favourable aspects of this report were confirmed by Chadwick's Report two years later (1842). In summary form, the principal streets were well-drained, there was a good supply of water, there were no cellar habitations, fever was not prevalent, and some allotment gardens remained. As for back-to-back houses, they were very common, but again the point was made that they were not necessarily a bad form of housing, provided the rooms were large and lofty and had chimneys, and that the doors and windows were of a good size; diseases were just as common in houses of different construction..$^{21}$ On the other hand, the Report laid greater emphasis on the bad state of the older courts, which were narrow, filthy, ill-ventilated and badly drained. The privies in these old courts were in a very bad state. It was the common practice to empty the ash pits and privies at night into the streets, and the contents would then be carted away the next morning, "though some filth always remains". It was also pointed out that although the water supply was generally ample, and there were pumps in nearly every court, the water was actually very bad in some of the courts near the river Rea, in Cheapside, Mill Street and Floodgate Street. ${ }^{22}$ The strongest condemnation was again reserved for the lodging houses. ${ }^{23}$

Chadwick's Report is different from the other reports of the 1840 's in that some indication is given of the actual plans and elevations of selected houses. The plans of an old court off Bromsgrove Street show that the entry into the court was extremely narrow - only 2 feet 11 inches, the court itself being only 4 feet 9 inches across. The houses themselves were either two- or three-storied, the three-storied facing onto the street. Houses with two floors had a ground-floor room measuring 11 feet 9 inches by 12 feet, the two first-floor rooms measuring 9 feet $4 \frac{1}{2}$ inches by 11 feet 9 inches, and 7 feet by 11 feet 9 inches. The height of the rooms was 7 feet 11 inches on the ground floor, 8 feet on the first, and 8 feet 2 inches when there was a third floor. Outside in the yard were privies and a shared brewhouse. The rent for a two-floored house was $3 /$ - per week, and for a three-floored house $4 / 6 \mathrm{~d} .{ }^{24}$

A short distance away, Bradford Street (parallel to and to the south of Digbeth High Street) provides an example of two new courts, one of ten houses, and the other of eleven houses. Entry to the courts was by passage-

${ }^{21}$ Chadwick's Report, p. 196.

22 Ibid., pp. 193-95.

23 Ibid., p. 197.

24 Ibid., between pp. 192 and 193. There is a photograph of a court in Bromsgrove Street in Chalklin, The Provincial Towns, plate 6, but it is clearly one of the newer courts. Both the entrance and the court itself are wider than the court depicted in Chadwick's Report, and the two-room house shown on the left dates from 1791. 
ways measuring 3 feet 3 inches - a slight improvement on the entries in Bromsgrove Street -, while the distance across each court to the line of brewhouses and privies separating the two courts was 12 feet 7 inches. Most of these houses were on three floors, with cellars, each room on each floor being 12 feet by 13 feet 7 inches. Room heights were: ground floor 7 feet 8 inches; first floor 8 feet; and second floor 7 feet 2 inches. Clearly these houses were larger than those in the courts off Bromsgrove Street, and the courts were much more spacious.

Chadwick's Report also gives an example of back-to-back houses in Great Russell Street. ${ }^{25}$ The houses here were three stories high with two rooms on the ground floor, 10 feet 9 inches by 13 feet, and 8 feet 9 inches by 13 feet; the larger of these rooms contained a pantry and the stairs. Upstairs there were two further rooms on the first floor, and an additional room on the second floor. The height of the first-floor rooms was 7 feet 9 inches, but that of the top floor only 5 feet 2 inches. Outside in front of each house was a yard with one brewhouse and one privy for every four houses.

Another type of house illustrated in this report was the so-called threequarters house. Houses of this kind were built in pairs, with a central tunnel entrance and front doors opening to the left and right off this passageway. Each house had a ground-floor parlour at the front (13 by 12 feet), and a kitchen of the same dimensions at the rear. Above were two bedrooms on the first floor, and two on the second. At the back there was a brewhouse and a privy for each house. Houses of this type in Tennant Street, near Broad Street, were rented at $£ 18$ per annum ( $7 /-$ a week), and appear to be of a superior kind. At the other extreme are court houses rented at only 2/6d a week in Ann Street (off Livery Street) and in the Pershore Road. The first had only two rooms, one up and one down (ground floor 12 feet 3 inches by 12 feet), and the second house three one-room floors (ground floor 14 feet 4 inches by 11 feet 8 inches).

The Second Report of the Commissioners of Inquiry into the State of Large Towns and Populous Districts (1845) adds little to the information provided by the earlier Reports, but does lay greater stress on the bad condition of the older courts, where the entrance was too narrow for refuse carts to enter. This meant that barrows or baskets had to be used. A survey of 202 older courts between Summer Row and Snow Hill revealed that 139 were in a bad state of repair. Only 19 were held to be excellent with respect to level, drainage and repair. ${ }^{26}$

${ }^{25}$ This street is presumably Russell Street, off Steelhouse Lane, which is shown on Hanson's 1795 map, but has long since disappeared completely.

26 1845 Report, Pt I, Appendix, pp. 2-4, 28. 
Four years after this report a petition was presented by more than a tenth of the ratepayers, asking that the terms of the Public Health Act (1848) be applied to the town. The result was a Report by Sir Robert Rawlinson to the General Board of Health on sanitary conditions in Birmingham (1849). Once more the advantages of the town were remarked upon, but at the same time the bad state of the older courts was again emphasised; there were about 2,000 close courts undrained, and many were unpaved, and the privies politely termed "a frequent source of nuisance". A survey of 285 courts in both the old and the newer parts of the town gave the following results.

\begin{tabular}{|c|c|c|c|c|c|c|c|c|}
\hline \multicolumn{3}{|c|}{ Drainage } & \multicolumn{3}{|c|}{ Level } & \multicolumn{3}{|c|}{ Repair } \\
\hline Good & $\mathrm{Bad}$ & Imperfect & Good & $\mathrm{Bad}$ & Imperfect & Good & $\mathrm{Bad}$ & Imperfect \\
\hline 134 & 74 & 77 & 134 & 49 & 99 & 159 & 43 & 78 \\
\hline & & & $\begin{array}{r}\text { W } \\
\text { Good }\end{array}$ & $\begin{array}{r}\mathrm{Ba} \\
\mathrm{Ba}\end{array}$ & $\begin{array}{l}\text { upply } \\
\text { None }\end{array}$ & & & \\
\hline & & & 177 & 80 & 20 & & & \\
\hline
\end{tabular}

In the majority of cases, there was one privy to every four houses. ${ }^{27}$

However, some of the new houses in the suburbs with rents at 5/- per week were better designed. The report contains plans of cottages in Bridge Street West with cellar, two ground-floor rooms, two bedrooms above, a washhouse or brewhouse, a privy and a pump. Gardens are shown in the plans, back and front. According to Rawlinson these cottages had "a clean, neat, and cheerful appearance when new", but they lacked a full supply of pure water, for the cesspool next to the privy could not fail to percolate into the well. There was also a lack of proper drainage. This applied to new housing on the outskirts, whether working-class or middle-class. "The new streets on the outskirts are in a most neglected state for want of power to drain and pave them, and many of the best houses drain into the public road." 28

How is this mass of new working-class housing erected before 1840 to be assessed? The Reports are unanimous in claiming that housing conditions were better in Birmingham than in many other large industrial towns. The 1845 Report, for example, states that Birmingham was "perhaps one of the most healthy of our large towns", and gives mortality percentages for the

${ }^{27}$ R. Rawlinson, Report to the General Board of Health on [ . . . ] the Borough of Birmingham (1849), pp. 23, 95.

${ }^{28}$ Ibid., p. 29. 
three years 1840, 1841 and 1842: Bath 2.6; Birmingham 2.7; Bristol 3.1; Dudley 2.6; Hull 3; Liverpool 3.5; Manchester 3.2; Wolverhampton 2.8. ${ }^{29}$ Whether the type of building erected in the last decades of the eighteenth century was inferior to housing which went up before 1750 has already been touched upon, but it would appear that the court dwelling houses built in the 1820 's and 1830 's were slightly more spacious both in room size and the size of entries and courts than those built earlier. So the design of building may have improved modestly in the early nineteenth century as compared with the late eighteenth century. But there was a noticeable variation in the amount and quality of accommodation offered from one part of the town to another. The skilled and better-paid workman might pay as much as $7 /-$ per week for a three-quarter house in Tennant Street, while a labourer would pay only $2 / 6 \mathrm{~d}$ a week for a court house in Ann Street. The worst accommodation, of course, was in the older courts and in the lodging houses.

As for the actual size of rooms, they seem similar to, and in some cases larger than, those in working-class housing elsewhere, and three-storied housing was an advantage not always found in other towns. The superior houses in Tennant Street had as much as 936 square feet in floor space, and even the back-to-back houses in Great Russell Street had 759 square feet, including attic space. Two-storied houses in the new courts off Bradford Street had rather less room, about 504 square feet. By way of comparison, the mass of back-to-back houses built in Leeds between 1815 and 1830 had a floor area of 450 square feet. ${ }^{30}$ In Coventry weavers' houses built in the 1830 's had about 530 square feet of room space. In the 1850's both weavers' and journeymen watchmakers' houses contained about 730 square feet. ${ }^{31}$ In Stourbridge in the Black Country the size of workers' houses varied from the smallest and meanest with only 250 to 350 square feet to the largest houses at 600 to 700 square feet. ${ }^{32}$

Birmingham does not come out badly in these comparisons, but of more importance than the actual room sizes was the amount of overcrowding, the quality of construction, and the provision of amenities such as adequate water supply. Although there may well have been some overcrowding in the 1780 's - it was said that there were greater changes in the appearance

291845 Report, Pt I, Appendix, p. 1; cf. 1844 Report, Appendix, p. 2.

${ }^{30}$ S. D. Chapman and J. N. Bartlett, "The Contribution of Building Clubs and Freehold Land Society to Working-Class Housing in Birmingham", in: The History of Working Class Housing. A Symposium, ed. by S. D. Chapman (1971), pp. 232-35.

${ }^{31}$ Calculated from the scale drawings in J. Prest, The Industrial Revolution in Coventry (1960), pp. 74, 82 .

32 Hopkins, "Working-Class Housing in the Smaller Industrial Town", loc. cit., tables I-VIII. 
of the town in this decade because of building than in the preceding forty years ${ }^{33}-$, nevertheless the Reports are unanimous that cellars were not lived in, and that each family had separate accommodation. Thus overcrowding was not a long-term problem. Water supply was certainly better than in some other industrial towns, though not in all parts; but there are very few references in the Reports to the need to buy water from carts, which is so common a feature in the description of other towns at this time. The quality of building, of course, remains difficult to ascertain. It clearly varied in nature, and some housing was undoubtedly jerry-built. Rawlinson drew attention to houses with external walls only $4 \frac{1}{2}$ inches thick, and with joists "too slender and far apart". The disadvantages of such houses was that although tenants could easily be found when they were new, they soon deteriorated, and the tenants would move on as the new street, without drains, pavements or public light, went into decline. In this way, according to Rawlinson, "district after district is vitiated". ${ }^{34}$

A survey of the kind just undertaken naturally gives rise to a number of queries and considerations which require comment; foremost among them must be the question of how accurate are the Reports of the 1840's. How far do they give a fair representation of the state of working-class housing at the time? In general terms, the reports on Birmingham give few indications of biassed reporting, although the 1840 Report probably passed too lightly over the state of the older courts, a fault corrected in all the subsequent Reports. Chadwick's Report, with its plans and elevations, is perhaps the fullest of all the Birmingham surveys, and is unique among the local reports in being prepared by a Committee of Physicians and Surgeons as opposed to a report submitted by an individual; though whether this makes it more or less trustworthy is difficult to say. Presumably it ought to be more comprehensive, at least, being based on a variety of opinions. In his lengthy introduction to his edition of Chadwick's Report, Professor Michael Flinn offers no comment on the accuracy or otherwise of the local reports, from which one might infer that he thought them reliable enough as evidence..$^{35}$

${ }^{33}$ Langford, A Century of Birmingham Life, op. cit., I, pp. 302, 308. Chalklin, The Provincial Towns, pp. 197, 305-06, considers that there might have been some multiple occupancy, with an average of six persons per house in 1778 and again in 1781 , but that the problem of overcrowding was overcome by 1801 , when the average number of persons per house fell to 4.4 . Thus in the 1780 's building kept up with the expansion in population, and also with the more limited growth in the 1790's. Between 1750 and 1820 , Birmingham builders faced a five-fold increase in numbers, but by 1820 the pattern of one family to a dwelling was the norm.

34 Rawlinson, Report to the General Board of Health, op. cit., p. 25

${ }^{35}$ E. Chadwick, Report on the Sanitary Condition of the Labouring Population of Gt. Britain (1842), ed. by M. W. Flinn (1965). 
We do not know, of course, how far the houses illustrated for Birmingham were typical, or what proportion of the total housing stock each kind of house constituted. Nevertheless, there is no concealment of the more unsavoury aspects of Birmingham housing of the time, and details of squalid conditions are repeated and extended in another source for descriptions of housing conditions in Birmingham, the well-known letters to the Morning Chronicle, published in 1850 and 1851.

According to the letters appearing in 1850 (actually, specially commissioned reports), the old courts in Birmingham were built on the model of those in Liverpool and were equally notorious, though not being so overcrowded on the whole as those in Liverpool, while cellar occupation was almost completely unknown. ${ }^{36}$ On the subject of working men's clubs, the Morning Chronicle reported that there were more than a hundred building clubs whereby the better-paid workmen might buy his house, and that such clubs erected "small and mean houses and cottages, built without any pretention to beauty, and very often of the flimsiest materials, or without proper regard being paid to the requirements of health or decency", yet of a quality which still exceeded that of speculative building in Lancashire. ${ }^{37}$ All in all, it appears a reasonable conclusion that the less creditable aspects of Birmingham housing are given a fair prominence in the local reports, and there is no reason to suppose that local reporters concealed or glossed over deficiencies in Birmingham's housing. ${ }^{38}$

Another major problem in assessing the quality of working-class housing in Birmingham in the mid nineteenth century is the extent of the older courts and the conditions therein. According to the 1845 Report, there

${ }_{36}$ Morning Chronicle, 7 and 14 October 1850.

${ }^{37}$ Ibid., 10 March 1851. For a modern account of Birmingham building clubs, see Chapman and Bartlett, "The Contribution of Building Clubs and Freehold Land Society", loc. cit. The statement quoted may appear to contradict the view expressed earlier that building-club houses were larger than average, but it will be realised that the previous reference was to eighteenth-century houses, and the remark that their quality was better than that of speculative building in Lancashire is noteworthy.

38 This point has some importance in that Dennis, English Industrial Cities of the Nineteenth Century, op. cit., p. 17, suggests that the Reports before 1845 noted that the newest housing in Birmingham, e.g., in Bordesley (not Borderley) was just as jerry-built and badly drained as new housing in Manchester; and this he regards as an indication that civic pride (presumably on the part of the Mayor and committee who gave evidence to the Commission) in the 1845 Report underestimated the housing problems in Birmingham. In fact, the reference to the Reports before 1845 must be to the 1840 Report, which states that the streets and drainage in Birmingham were very superior to those in Manchester and other towns in Lancashirè (q. 2,269), save in one district, Bordesley, where there were numerous back-to-back and chiefly modern houses; but this was not so in other districts (qq. 2,270, 2,274-75). 
were in the parish of Birmingham alone more than 2,000 courts containing more than 50,000 inhabitants, that is, nearly a fifth of the total population of the borough of Birmingham in 1851 of $232,841 .{ }^{39}$ However, we are not told whether these were all older courts, or a mixture of old and new. The same figure of 2,000 courts appears in Rawlinson's Report, but this time the reference is to "about 2,000 close courts, undrained" ${ }^{40}$ It is difficult to take this line of enquiry much further, so that one is left with the conclusion that the older and fouler courts formed a substantial part of the housing stock at the mid century, but were probably part of the eighteenth-century legacy of the poorest kind of working-class housing. It is tempting to view the numerous back-to-back houses also as part of this legacy, but in fact they were built in the nineteenth century as well, and continued to be built throughout the first half of this century. The problem here is to determine how bad this type of housing really was in Birmingham. It has already been noted that according to the 1842 Report this kind of house was not necessarily of the worst quality, and some were certainly far more spacious than back-to-backs in Leeds, for example. Indeed, the 1842 Committee of Physicians and Surgeons remarked (rather quaintly, one might think) that even if the back-to-backs could be separated by a few yards, the resulting back yards or passages would only be used for pigs, rabbits or poultry, and made the receptacles for rubbish and filth. Thus the prevailing belief that lack of through ventilation necessarily made the back-to-back an unacceptable kind of house was vigorously rebutted by the 1842 Committee. ${ }^{41}$

It can be argued, of course, that the main shortcoming of the worst working-class housing in Birmingham in the mid nineteenth century was not so much the poor fabric, cramped accommodation, or lack of water supply or regular scavenging, but the inadequacy of the privies. As was so common elsewhere, privies were rarely emptied regularly, and when in addition some courts lacked all forms of drainage, it is obvious that the older courts especially were highly insanitary. Nevertheless, living conditions in early-nineteenth-century Birmingham must be seen in perspective. For most immigrants into the town from the countryside, the spaciousness of the housing might well be an improvement on their country cottages, and privies and middenheaps with their offensive sights and smells were familiar enough to them. ${ }^{42}$ Even where water closets were installed in

\footnotetext{
391845 Report, Pt I, Appendix, p. 2; printed Census Returns, 1851.

40 Rawlinson, Report to the General Board of Health, p. 23.

${ }^{41}$ Chadwick's Report, p. 196.

${ }^{42}$ For the state of rural housing at the time, see J. Burnett, A Social History of Housing, 1815-1970 (1978), ch. 2. Dr Burnett considers that the agricultural worker was almost certainly the worst housed among fully employed workers, p. 31.
} 
middle-class streets in Birmingham, they were still characterised by objectionable smells. Thus, in the Hagley Road there were no drains, and the water closets discharged their contents into open ditches on each side of the road. There were also cesspits on many premises in this road. In 1849 workmen engaged for $£ 2$ to empty one cesspit found the smell so bad that they demanded an additional $£ 1$, and then a further $£ 1$ and a pint of brandy every hour. ${ }^{43}$ Again, even when some houses possessed water closets in Deritend, the situation might be just as unpleasant. Dr Joseph Hodson, by this time Medical Sanitary Inspector for the Corporation of Birmingham, put this very feelingly.

I would advise you to call at a butcher's shop near Deritend, and when you are sitting in the butcher's parlour it might happen to you as it did to me, that someone used a water closet of a neighbouring house, and the water and everything was discharged, so to speak, smack in our faces. ${ }^{41}$

Thus both middle-class and working-class families might suffer from inadequate sanitation, though of course the middle classes had the advantage of much more spacious accommodation, often in detached villas. By the mid nineteenth century most of the middle classes had removed to the outskirts, though a few remained in the more central parts. As Chadwick put it, "The more opulent inhabitants live in the country, and comparatively few in the town - but few parts do not have some better houses inhabited by master manufacturers or managers." 45

For the working classes, all turned on the occupation of the householder and the extent of the family income; as already pointed out, the tenant who was a skilled workman and in regular employment could afford a higher rent and enjoy better housing than the unskilled labourer. Again according to the Chadwick Report, there was a considerable range of working-class incomes in the 1840 's, the better-paid earning as much as $30 /-$ to $50 /-$ a week. A survey in the report of the earnings of 623 males and 164 females in 110 different occupations shows an average wage for males in the age range 21 to 70 of $£ 14 / 2 \mathrm{~d} .{ }^{46}$ Where the wife and/or children were also working, this would be an additional factor in determining the rent which could be afforded and the area of residence. Closely associated with this would be the place of work of the householder, if working outside the home; since workmen needed to live reasonably close to their work, those in the same industry tended to live near each other. This seems to apply in Birmingham

\footnotetext{
43 Rawlinson, Report to the General Board of Health, p. 26.

44 Ibid., p. 83.

45 Chadwick's Report, p. 194.

46 Ibid., pp. 209-10.
} 
(and elsewhere in the Black Country) even when the occupation was based on a domestic workshop. Thus, in the gun trade there was a strong concentration of workshops and housing occupied by workers in the gun trade in the area of St Mary's, while jewellery workers were concentrated very largely on the Newhall estate and the adjacent Vyse estate. On the other hand, the button trade was more dependent on the labour of women and children, so the housing of these button workers was more dispersed, dependent on the occupation of the male householder, and often in the gun and jewellery quarters. Since the brass foundries were widely dispersed, there was a widely scattered residential pattern of brass workers, too. ${ }^{47}$

To sum up: working-class housing in Birmingham at the end of the 1840's the end of the period conventionally ascribed to the Industrial Revolutionappears to have been somewhat better than similar housing in other large industrial towns of the time. This may be in part the consequence of its geographical advantages such as its natural drainage, the availability of land for building, and a relatively good supply of water; but a more important cause may well be that the pressure of population growth in the first half of the nineteenth century was less than in other great industrial towns. It may also be important that there was extensive skilled employment in Birmingham, so that rather higher rents could be afforded than elsewhere..$^{48} \mathrm{Of}$ course, if population pressure was less in the first half of the nineteenth century, it must be acknowledged that it was very marked in the 1770 's and 1780 's, which may account at least in part for the relatively poor housing and cramped conditions in the older courts by the 1840's. These courts were undoubtedly a black spot by this time.

Secondly, on the basis of Chadwick's Report it appears that there was considerable variation in the kind of house built, ranging from houses with five rooms or more on three floors to the most primitive kind with only one room up and one room down. ${ }^{49}$ The room space in the houses on the whole seems to contrast very favourably with the space available in working-class homes elsewhere. Houses erected by building clubs (terminating building

${ }^{47}$ J. E. Vance, Jr, "Housing the Worker: Determinative and Contingent Ties in Nineteenth Century Birmingham", in: Economic Geography, XLIII (1967).

48 The Morning Chronicle, 7 October 1850, claimed that "In Birmingham a labourer must be skilled to have the slightest chance of obtaining a livelihood. Accordingly, it is the mechanic, not the mere labouring man, that is in request".

49 The Morning Chronicle, 14 October, gives an example of some houses with only one room. This room was on the first floor, and was reached by an external ladder, the ground floor being occupied by an ashpit, a privy and a brewhouse. Such houses must have been exceptional. For interesting and rarely attempted definitions of ashpits, cesspools and middens, see Daunton, House and Home in the Victorian City, op. cit., p. 248. 
societies) were apparently not greatly superior in nature to other workingclass houses, but their very existence indicates that a significant proportion of the Birmingham working classes were earning good and steady wages. ${ }^{50}$ As for back-to-backs, they were certainly built in considerable numbers, but should not be regarded as a sign of universally squalid conditions; they could be surprisingly roomy and, if the Reports are to be believed, were not especially unhealthy. ${ }^{51}$ There were still 43,000 of them in 1914 , though by that time many of the older, closed courts had been opened up by the demolition by the Corporation of one side of the court, thus permitting a much greater influx of air. It may be noted that in the 1980's back-to-back houses are again being built in the Greater London area as a cheap form of starter homes.

Lastly, to this picture of considerable variation in the type of workingclass house built during the period of the Industrial Revolution in Birmingham, there must be added the geographical segregation of the middle classes and the working classes, together with the segregation of different occupational groups within the working classes themselves dependent on the siting of the major industries. To answer the question posed at the beginning of this paper, how may the development of working-class housing in Birmingham during the Industrial Revolution be seen against the national background, it may be said that Birmingham housing exhibits many of the features to be seen elsewhere, but supplies a good example of variety of design and construction, with an overall quality of accommodation probably superior to that provided by any of the other great industrial towns of the period.

50 For further details of Birmingham building clubs, see the sources quoted in note 37.

51 Daunton, House and Home in the Victorian City, pp. 29-30, estimates that backto-back houses in Birmingham accommodated two-thirds of the town's population at the mid nineteenth century. This figure may be over-generous, but undoubtedly their numbers were large. 